Molecules 2001, 6, 803-814

molecules

ISSN 1420-3049

http://www.mdpi.org

\title{
Synthesis of the Aspidosperma Alkaloid $\mathrm{N}_{\mathrm{a}}$-Formyl-16- $\alpha$ - Hydroxyaspidospermidine
}

\section{Fatiha Belferdi and Abdelhamid Belattar*}

Department of Chemistry, Faculty of Science, Constantine University, 25000, Algeria.

* Author to whom correspondence should be addressed; e-mail: a.belattar@caramail.com

Received: 1 April 2001; in revised form 6 September 2001 / Accepted: 8 September 2001 / Published: 30 September 2001

\begin{abstract}
The first total synthesis of $\mathrm{N}_{\mathrm{a}}$-formyl-16 $\alpha$-hydroxyaspidospermidine and its isomer via $( \pm)$-vincadifformine is described and their structure elucidation using different methods of analysis is reported.
\end{abstract}

Keywords: Aspidosperma alkaloid, Rhazia stricta, strictanine, spegazzinine

\section{Introduction}

The indole alkaloid strictanine (1b) was recently isolated from the fruit of Rhazia stricta Decsne [1] which is an indigenous medicinal plant abundantly found in Pakistan. This medicinal plant has long been used for the treatment of various diseases $[2,3]$. We report here the first total synthesis of this compound starting from ( \pm )-vincadifformine (2), which was previously prepared from tryptamine hydrochloride by an adaptation of Kuehne's biomimetic synthesis [4, 5]. This prompted us to extend it to more oxygenated alkaloids such as spegazzinine (10a) and spegazzinidine (10b) [6].

\section{Results and Discussion}

The existing literature method for the conversion of the readily available ( \pm )-vincadifformine (2) into the key intermediate 16-hydroxyindolenine (3) showed that the latter compound is particularly 
unstable [7, 8]. Similarly, photo-oxygenation [9] of 2 in the presence of Rose Bengal and sodium thiosulphate as reducing agent to give 16-hydroxyindolenine (3) resulted in low yields of the desired compound. The other product was mainly recovered starting material. This is undoubtely due to the different tungsten lamps used $(2 \times 150 \mathrm{~W})$. Le Men and co-workers [10] also achieved this convertion in vitro through a multi-step procedure involving the prior oxidation with peroxyacids to afford the 16hydroxy-1,2-dehydrovincadifformine- $\mathrm{N}_{\mathrm{b}}$-oxide (4) in which the $\mathrm{N}_{\mathrm{b}}$ centre was blocked to avoid any spontaneous rearrangement.

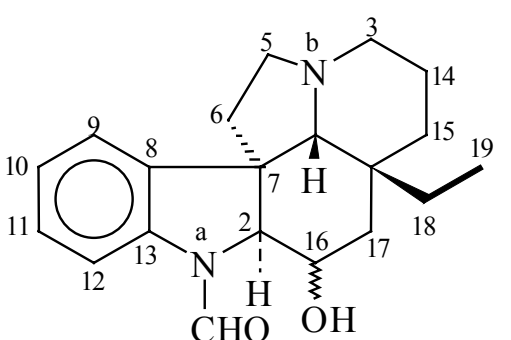

( 1 ) a. $16 B-\mathrm{OH}$

b. $16 a-\mathrm{OH}$<smiles>CC[C@]12CCC[N+]3([O-])CC[C@@H]4c5ccccc5N[C@@H]4C(=O)C[C@H]1[C@H]23</smiles>

( 5 ) $\underset{\text { a. }}{\text { a }} \mathrm{N}_{\mathrm{b}}$-oxide<smiles>CC[C@H]1[C@@]2(CC)CCCN3CC[C@]14c1ccccc1N[C@H]4[C@H](O)C[C@H]32</smiles>

( 6 ) a. $16 B-\mathrm{OH}$

b. $16 a-\mathrm{OH}$<smiles>CC[C@]12CCCN3CC[C@]4(c5ccc(OC)c(OC)c5N(C)[C@H]4C(=O)C1)C32</smiles>

( 8 )

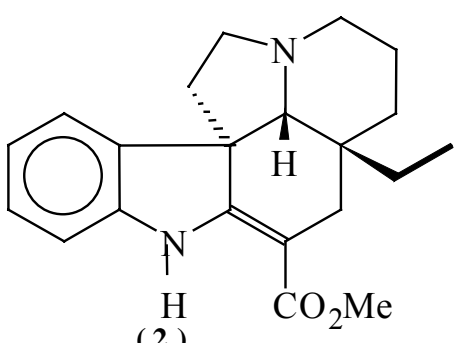

(2)<smiles>CC[C@@H]1[C@]23CCN4CCC[C@@]1(CC)[C@@H]4CC(O)(C(=O)O)C2=Nc1ccccc13</smiles>

(4) $\mathrm{N}_{\mathrm{b}}$-oxide

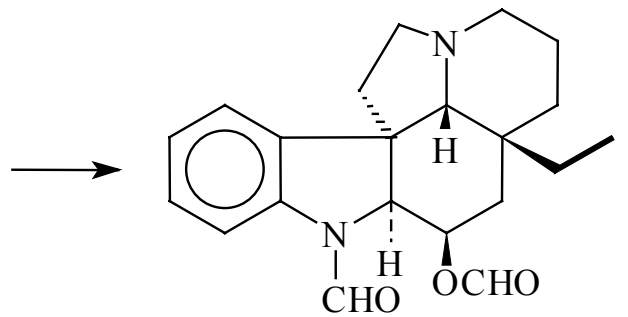

( 7 ) a. y: $90 \%$

b. $y: 77 \%$<smiles>CC[C@@]12CCCN3CC[C@@]4(C1)C(=Nc1ccccc14)CC32</smiles><smiles>[R]c1ccc2c(c1[R2])N(C)[C@H]1[C@@H](O)C[C@]3(CC)CCCN4CC[C@@]23[C@@H]14</smiles>

(9)

b. $\mathrm{R}_{1}=\mathrm{OH}, \mathrm{R}_{2}=\mathrm{OH}$ 
Reaction of vincadifformine (2) with $\underline{m}$-chloroperbenzoic acid in dry benzene gave, after evaporation of the solvent, a variable yield of 16-hydroxyindolenine- $\mathrm{N}_{\mathrm{b}}$-oxide derivative 4 . However, an essentially quantitative yield of $\mathbf{4}$ was obtained after solvent removal under reduced pressure $\left(\mathrm{t}_{\text {bath }}<\right.$ $40^{\circ} \mathrm{C}$ ) when vincadifformine was treated with 3 equivalents of $\underline{\mathrm{m}}$-chloroperbenzoic acid in the dark for $36 \mathrm{~h}$ under a nitrogen atmosphere.

The molecular ion was observed at $\mathrm{m} / \mathrm{z} 370$, in agreement with the empirical formula $\mathrm{C}_{21} \mathrm{H}_{26} \mathrm{~N}_{2} \mathrm{O}_{4}$ which was also supported by microanalysis. The UV spectrum in methanol gave maxima at 223 and $270 \mathrm{~nm}$ and the IR spectrum indicated a non conjugated ester at $1738 \mathrm{~cm}^{-1}$ (in contrast with the absorptions at $v_{\max } 1670$ and $1610 \mathrm{~cm}^{-1}$ in the starting material) and a hydroxy group at $3450 \mathrm{~cm}^{-1}$. The ${ }^{1} \mathrm{H}-\mathrm{NMR}$ spectrum showed a multiplet at $8 \mathrm{ppm}(\mathrm{OH})$, a doublet due to the C-9 proton at $7.6 \mathrm{ppm}$, a multiplet at 7.5-7.1 (3 ArH), the methoxycarbonylmethyl group at $3.95 \mathrm{ppm}$ and the $\mathrm{C}-18$ methyl group as a triplet at $0.5 \mathrm{ppm}$. Subsequent hydrolysis with $1.25 \mathrm{M}$ sodium hydroxide solution, followed by decarboxylation under acidic conditions $(\mathrm{pH}=1)$ at $100^{\circ} \mathrm{C}$ for $20 \mathrm{~min}$, produced the desired product $\mathbf{5 a}$ as a yellow amorphous solid in $98 \%$ yield. The presence of the carbonyl function in $\mathbf{5 a}$ was confirmed by the long wavelength absorption observed in the UV spectrum $\left[\lambda_{\max } 218,243\right.$ (sh), 300 $\mathrm{nm}$ ] typical of the indolinic compound and by the absorption in the IR spectrum at $1720 \mathrm{~cm}^{-1}$ (CO). The molecular ion in the mass spectrum was observed at $\mathrm{m} / \mathrm{z} 312$ and was consistent with the molecular formula $\mathrm{C}_{19} \mathrm{H}_{24} \mathrm{~N}_{2} \mathrm{O}_{2}$.

\section{Scheme 1}

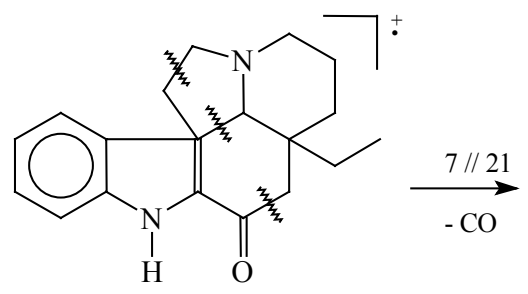

$5 \mathbf{b}$
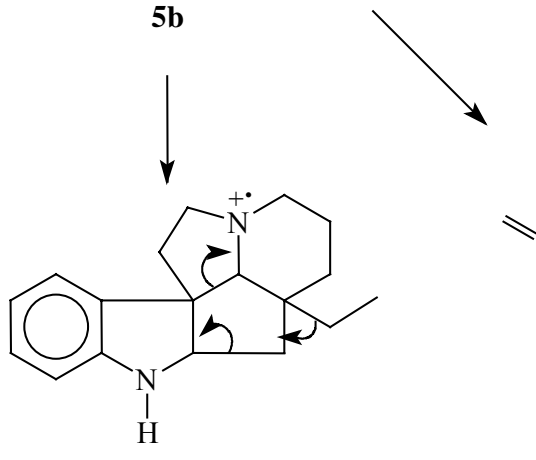

a, $\mathrm{m} / \mathrm{z} 268$

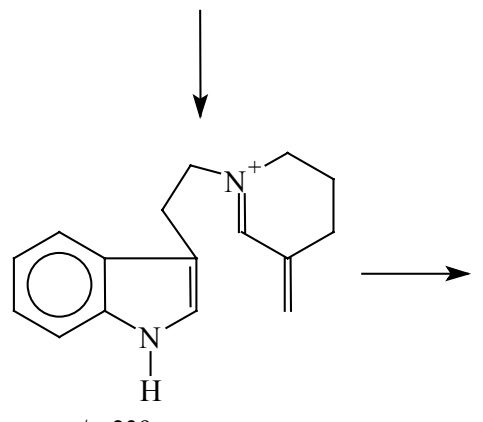

$\mathrm{m} / \mathrm{z} 239$

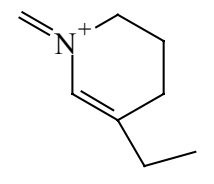

$\mathrm{m} / \mathrm{z} 124(18.1 \%)$

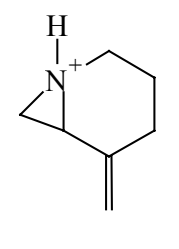

$\mathrm{m} / \mathrm{z} 110$

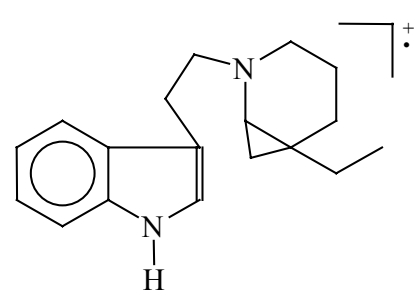

b, $\mathrm{m} / \mathrm{z} 268$
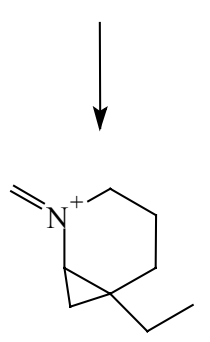

c, $\mathrm{m} / \mathrm{z} 138(100 \%)$

$\mathrm{m} / \mathrm{z} 130$ 
Attempts to reduce the N-oxide group with palladium-hydrogen gave a low yield $(32 \%)$ of $\mathbf{5 b}$ whereas Adam's catalyst $\left(\mathrm{PtO}_{2}\right)$ and hydrogen at atmospheric pressure afforded a good yield (80\%). However, the major mass spectral fragment of $\mathbf{5 b}$ was not observed at $\mathrm{m} / \mathrm{z} 124$ as for vincadifformine and its derivatives. Instead, the molecule exhibits a $\mathrm{M}^{+}-28$ peak at $\mathrm{m} / \mathrm{z} 268$ and shows its most intense peak at $\mathrm{m} / \mathrm{z}=138$, which is also observed in the 16-dehydrospegazzinidine dimethyl ether 8 [11]. Consequently, the retro Diels-Alder fragmentation is less important in compound such as $\mathbf{5 b}$ with a carbonyl group at $\mathrm{C}$-16 which thus alters the typical aspidospermine mass spectral fragmentation pattern. The molecular ion decomposes by expulsion of carbon monoxide to give species $\mathbf{b}$ $(\mathrm{m} / \mathrm{z}=268)$. Subsequent fission of the $\mathrm{C}-5, \mathrm{C}-6$ bond therefore produces not the anticipated ion at $\mathrm{m} / \mathrm{z}$ 124 , but rather the ion $\mathbf{c}(\mathrm{m} / \mathrm{z} 138,100 \%)$ as the major fragment (Scheme 1).

16-Oxoaspidospermidine $\mathbf{5 b}$, when subjected to reduction with sodium borohydride in ethanol, followed by heating, gave a mixture of C-16 epimers, which were separated by column chromatography on kieselgel G using chloroform - methanol (9:1) as eluent. The major product (less polar, $72.5 \%$ ) was $16 \alpha-\mathrm{H}, 16 \beta-\mathrm{OH}$ aspidospermidine $6 \mathbf{a}$, obtained as colourless plates (m.p. $55^{\circ} \mathrm{C}$ ), which exhibited UV absorptions at $\lambda_{\max } 212,244$ and $300 \mathrm{~nm}$. The exact structure of this compound was deduced from its ${ }^{1} \mathrm{H}-\mathrm{NMR}$ spectrum which exhibited signals clearly indicating that a coupling constant $(\mathrm{J}=4 \mathrm{~Hz})$ of $\mathrm{H}-2(\mathrm{~d}, 3.77 \mathrm{ppm})$ and $\mathrm{H}-16(\mathrm{~m}, 4.85 \mathrm{ppm})$ that is compatible with a cis configuration $(2 \alpha-\mathrm{H}, 16 \alpha-\mathrm{H})$. Irradiation of $16-\mathrm{H}$ gave $\mathrm{C}-2$ as a singlet at $3.75 \mathrm{ppm}$. Therefore the configuration of the hydroxyl group is $\beta$. The ${ }^{13} \mathrm{C}-\mathrm{NMR}$ spectrum showed nineteen resonances with the $\mathrm{C}-16$ atom giving rise to the resonance at $\delta 67.65 \mathrm{ppm}$. The more polar product $(6 \mathbf{b}, 12.5 \%)$ was found to be epimeric at C-16 and was compared with that also obtained by Le Men et al. [10] from the indolenine 9. Reaction of 16 $\beta$-hydroxyaspidospermidine $\mathbf{6 a}$ with formic acid and acetic anhydride afforded the N,O-diformyl derivative 7a in $90 \%$ yield as colorless plates (m.p.70-72 ${ }^{\circ} \mathrm{C}$ ). The infrared spectrum indicated the presence of two characteristic absorptions at 1720 (OCHO) and $1670 \mathrm{~cm}^{-1}$ (NCHO) with no free $\mathrm{NH}$ group. In the ${ }^{1} \mathrm{H}-\mathrm{NMR}$ spectrum, the two singlets which correspond to the two formyl functions (OCHO) and (NCHO) were observed at 8.9 and $8.6 \mathrm{ppm}$ respectively. Data from the ${ }^{13} \mathrm{C}$-NMR spectra are reported in Table 1 for comparison.

Table 1. ${ }^{13} \mathrm{C}$-NMR Data.

\begin{tabular}{|c|c|c|c|c|}
\hline Carbon $\mathbf{N}^{\circ}$ & $\mathbf{6 a}$ & $\mathbf{7 a}$ & $\mathbf{1 a}$ & $\mathbf{1 b}$ \\
\hline 2 & 70.01 & 70.14 & 71.84 & 71.39 \\
3 & 53.15 & 53.32 & 52.9 & 53.4 \\
5 & 52.49 & 51.89 & 52.47 & 52.64 \\
6 & 43 & 44.11 & 41.26 & 42.23 \\
7 & 54.0 & 66.4 & 65.23 & 64 \\
8 & 136.01 & 138.46 & 138 & 138.6 \\
9 & 123 & 123.17 & 124.15 & 123.52 \\
10 & 118.4 & 116.15 & 116 & $116(\mathrm{w})$ \\
\hline
\end{tabular}




\begin{tabular}{|c|c|c|c|c|}
\hline 11 & 127.61 & 124.79 & 125.11 & 125.43 \\
12 & 109.26 & 109.05 & 109.66 & 110.54 \\
13 & 150.35 & 140.97 & 142.23 & 142 \\
14 & 22.10 & 21.57 & 21.86 & 21.38 \\
15 & 34.7 & 32.76 & 33.62 & 32.78 \\
16 & 67.65 & 127.81 & 128.02 & 127.86 \\
17 & 35.97 & 34.84 & 35.46 & 31.30 \\
18 & 7.75 & 7.12 & 7.58 & 6.8 \\
19 & 34.23 & 32.15 & 34.35 & 34.31 \\
20 & 36.11 & 35.04 & 35.79 & 36.74 \\
21 & 74.49 & 71.05 & 74.09 & 73.85 \\
$\mathrm{~N} \underline{\mathrm{C} H O}$ & $\ldots .$. & 160.18 & 159.82 & 160.2 \\
O댕 & $\ldots .$. & 160.05 & $\ldots \ldots$. & $\ldots .$. \\
\end{tabular}

When sodium carbonate was added to a solution of the diformyl 7a compound in methanol the reaction produced $\mathrm{N}_{\mathrm{a}}$-formyl-16 $\beta$-hydroxyaspidospermidine (1a) in $98 \%$ yield (m.p. $66-68{ }^{\circ} \mathrm{C}$ ). The spectroscopic data suggested that the correct relative stereochemistry had been obtained. In the IR spectrum a broad absorption was seen at $3400 \mathrm{~cm}^{-1}(\mathrm{OH})$ and a strong absorption at $1680 \mathrm{~cm}^{-1}$ which was assigned to the $\mathrm{N}_{\mathrm{a}}$-formyl group. The UV spectrum in methanol is found to be essentially identical to that reported by Atta-Ur- Rahman [1] for the alkaloid strictanine (1b). The mass spectrum shows the anticipated fragmentation pattern (Scheme 2).

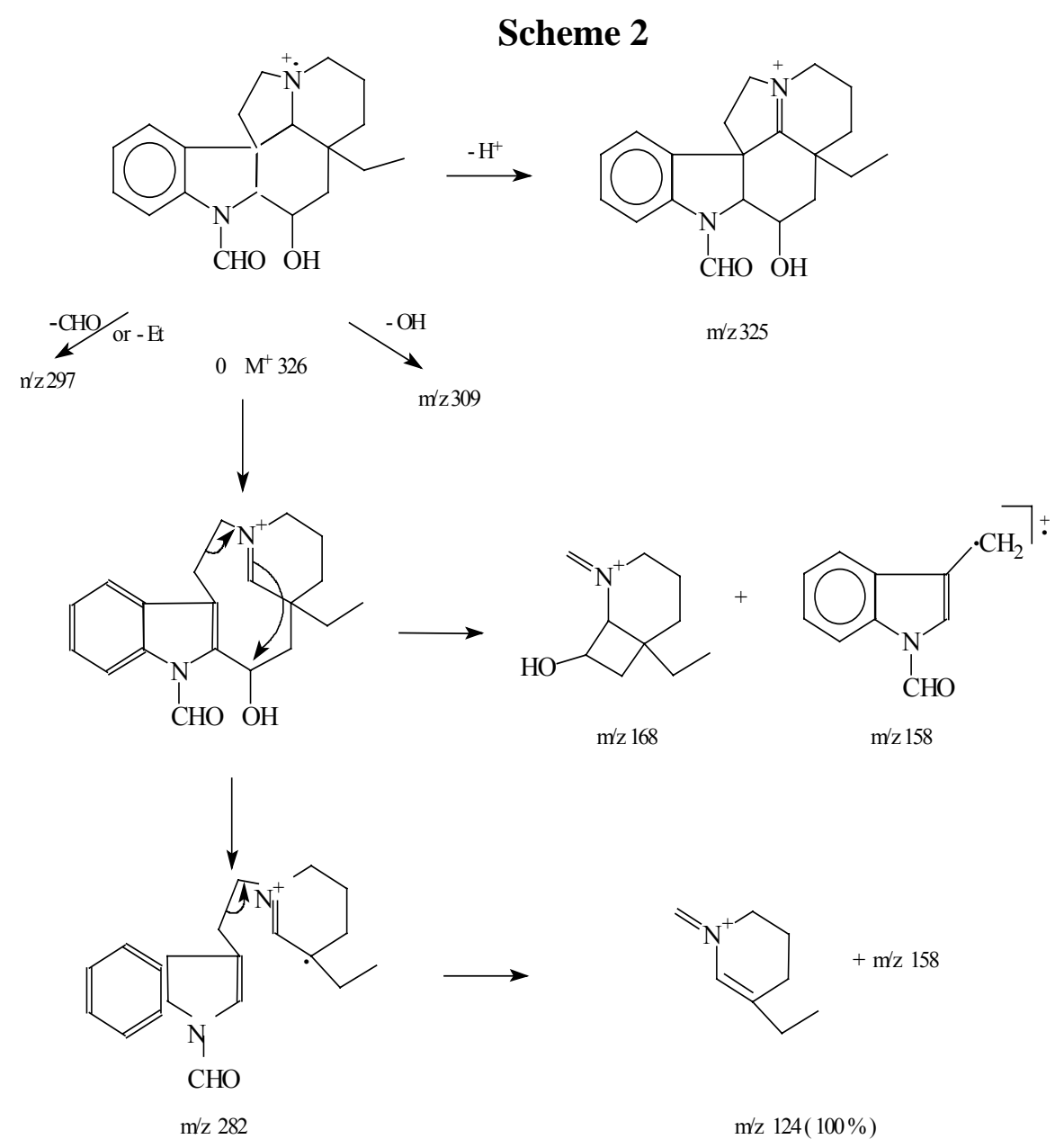


In the ${ }^{1} \mathrm{H}-\mathrm{NMR}$ spectrum the $\mathrm{N}$-formyl proton (NCHO) was seen as two singlets (relative intensity 7:1) at 9 and 8.72 ppm respectively. Saturation of one peak caused the disappearance of the other one. These are the two s-cis/s-trans geometrical isomers resulting from restricted rotation, well-known for amides. The H-12 proton was observed as a doublet at $8.03 \mathrm{ppm}$ due to the ortho-coupling to $\mathrm{H}-11$

\section{Acknowledgements}

We wish to thank the Ministry of Education, Algeria, for financial support and we are indebted to Dr. J. Fisher (Leeds) and Dr. R. T. Brown (Manchester) for both recording and their useful discussions of the NMR spectra.

\section{Experimental}

\section{General}

Melting points were determined on a Kofler hot-stage apparatus and are uncorrected. IR spectra were recorded on either a Perkin-Elmer 1420 or a 1310 spectrophotometer. UV absorption spectra were obtained on a Unicam PU 8800 spectrometer. NMR spectra were recorded on either a JEOL FX90QFT (90 MHz for ${ }^{1} \mathrm{H}$ and ${ }^{13} \mathrm{C}$ ), a GE QE $300\left(300 \mathrm{MHz}\right.$ for ${ }^{1} \mathrm{H}$ and ${ }^{13} \mathrm{C}$ ) or a Bruker $400 \mathrm{MHz}$ spectrometer (400 MHz for ${ }^{1} \mathrm{H}$ and ${ }^{13} \mathrm{C}$ ). Solutions in deuteriochloroform, with tetramethylsilane as internal standard were used, unless otherwise stated. $J$ values are given in Hz. Mass spectra were recorded on a Kratos MS 25 instrument; accurate mass measurements were carried out on a AEI/Kratos MS 902/50 spectrometer.

\section{Preparation of aldimine}

Cyclohexylamine (49.59 g, $0.5 \mathrm{mmol}$ ) was placed in $250 \mathrm{~mL}$ three-necked, round bottomed flask fitted with a thermometer, mechanical stirrer, and an addition funnel, then cooled to $-5{ }^{\circ} \mathrm{C}$ in an icesalt bath. Butyraldehyde (36.05 g, $0.5 \mathrm{~mol})$ was carefully added dropwise at such a rate that the temperature remained below $5^{\circ} \mathrm{C}$. Stirring was continued for 30 minutes. The solution was then allowed to warm to room temperature, poured into a separatory funnel, and the water produced during the reaction was removed. The reaction was allowed to go to completion by leaving it standing for $24 \mathrm{~h}$ in the presence of $\mathrm{K}_{2} \mathrm{CO}_{3}(16 \mathrm{~g})$ and $\mathrm{KOH}$ pellets $(16 \mathrm{~g})$. Filtration followed by distillation gave the desired aldimine (65 g, 68\%) as a colorless liquid, b.p. 80-84 ${ }^{\circ} \mathrm{C} / 20 \mathrm{~mm} \mathrm{Hg} ;{ }^{1} \mathrm{H}-\mathrm{NMR}: \delta_{\mathrm{H}}\left(\mathrm{CDCl}_{3}, 90\right.$ Mz) $7.7(1 \mathrm{H}, \mathrm{t}, \mathrm{J}=5.14 \mathrm{~Hz},=\mathrm{C} \underline{\mathrm{H}}-), 3-1.2(14 \mathrm{H}, \mathrm{m})$, and $1 \mathrm{ppm}\left(3 \mathrm{H}, \mathrm{t}, \mathrm{J}: 7.4 \mathrm{~Hz},-\underline{\mathrm{C}}_{3}\right)$.

\section{Preparation of lithium diethylamide}

A solution of diethylamine $(7.31 \mathrm{~g}, 0.1 \mathrm{~mol})$, dry hexamethylphosphoramide $(17.92 \mathrm{~g}, 0.1 \mathrm{~mol})$, dry benzene $(20 \mathrm{~mL})$, and lithium $(0.69 \mathrm{~g}, 0.1 \mathrm{atmg})$ was stirred vigorously between $20-25^{\circ} \mathrm{C}$ for $3 \mathrm{~h}$. 


\section{Lithium salt of the imine}

Lithium diethylamide solution in dry tetrahydrofuran $(15 \mathrm{~mL})$ was cooled to $-60{ }^{\circ} \mathrm{C}$ and the imine $(15.3 \mathrm{~g}, 0.1 \mathrm{~mol})$ was added via a syringe at such a rate that the temperature remained between $-60^{\circ} \mathrm{C}$ and $-65^{\circ} \mathrm{C}$ during the addition. After 30 min stirring the reaction mixture was allowed to warm to -10 ${ }^{\circ} \mathrm{C}$ for $2 \mathrm{~h}$.

\section{Synthesis of chloroaldehyde}

To a stirred solution of 1-bromo-3-chloropropane (15.74 g, $0.1 \mathrm{~mol})$ in anhydrous tetrahydrofuran $(200 \mathrm{~mL})$, cooled to $-70^{\circ} \mathrm{C}$, the solution of the lithium salt of the aldimine was added dropwise via syringe. After the addition was complete the resulting reaction mixture was allowed to warm to $-10^{\circ} \mathrm{C}$ and kept there for $2 \mathrm{~h}$. Stirring was then continued overnight at room temperature. The reaction mixture was treated with $3 \mathrm{~N}$ hydrochloric acid at $-20^{\circ} \mathrm{C}$, then stirred at room temperature for $5 \mathrm{~h}$. The mixture was extracted with ether $\left(3 \times 150 \mathrm{~mL}\right.$ ). The combined ethereal layers were washed with $\mathrm{Na}_{2} \mathrm{CO}_{3}$ $(40 \mathrm{~mL})$, dried $\left(\mathrm{Na}_{2} \mathrm{SO}_{4}\right)$, and then concentrated under reduced pressure. The residue was purified by chromatography on Kieselgel G (180 g) using ethyl acetate as eluent to give 5-chloro-2-ethylpentanal (11.49 g, 77.4-89\%) as a colouress oil, b.p. $100^{\circ} \mathrm{C} / 0.5 \mathrm{mmHg}$; UV: $v_{\max }\left(\mathrm{CHCl}_{3}\right) 1720(\mathrm{CHO}), 650$ $\mathrm{cm}^{-1}$; ${ }^{1} \mathrm{H}-\mathrm{NMR}: \delta_{\mathrm{H}}\left(\mathrm{CDCl}_{3}, 90 \mathrm{MHz}\right) 9.5(1 \mathrm{H}, \mathrm{d}, \mathrm{J}=2.5 \mathrm{~Hz},-\mathrm{CHO}), 3.5\left(2 \mathrm{H}, \mathrm{m},-\mathrm{CH}_{2} \mathrm{Cl}\right), 2.4(2 \mathrm{H}, \mathrm{m})$, $1,8(4 \mathrm{H}, \mathrm{m})$, and $0.9\left(3 \mathrm{H}, \mathrm{t}, \mathrm{J}=7,2 \mathrm{~Hz},-\mathrm{CH}_{3}\right)$.

\section{Preparation of ( \pm )-vincadifformine (2)}

A mixture of 1-carbomethoxy-1-methyl-1,2,3,4-tetrahydro- $\beta$-carboline (5 g, $20.4 \mathrm{mmol})$, p-toluenesulphonic acid and 5-chloro-2-ethylpentanal $(3.66 \mathrm{~mL}, 24.9 \mathrm{mmmol})$ in toluene $(420 \mathrm{~mL})$ was refluxed for $100 \mathrm{~h}$ under a nitrogen atmosphere in a Dean-Stark apparatus. To the hot solution, diazabicycloundecene (DBU) $(6.33 \mathrm{~mL}, 49.9 \mathrm{mmol})$ was added and heating continued for $18 \mathrm{~h}$. The reaction mixture was allowed to cool to room temperature, then concentrated under reduced pressure. The brown residue was purified by chromatography on Kieselgel G (180 g), using dichloromethane ether $(7: 1)$ as eluent; this gave $( \pm)$ vincadifformine $(5.83 \mathrm{~g}, 81.2 \%)$, which was recrystallised from acetonitrile and obtained as colouress prisms; m. p. $125{ }^{\circ} \mathrm{C}$ (lit.[4], 124-25 ${ }^{\circ} \mathrm{C}$ ); Anal. Found: C, 74.65; H, 7.75; N, 8.3; calc. for $\mathrm{C}_{21} \mathrm{H}_{26} \mathrm{~N}_{2} \mathrm{O}_{2}: \mathrm{C}, 74.55 ; \mathrm{H}, 7.7 ; \mathrm{N}, 8.3 \%$; IR $v_{\max }\left(\mathrm{CHCl}_{3}\right) 3380(\mathrm{NH})$, $1720\left(\mathrm{CO}_{2} \mathrm{Me}\right), 1670,1610,1360,1050,750$ and $610 \mathrm{~cm}^{-1}$; UV $\lambda_{\max }(\mathrm{MeOH}) 222,296,324 \mathrm{~nm}$, and $\lambda_{\min } 256,304 \mathrm{~nm} ;{ }^{1} \mathrm{H}-\mathrm{NMR} \delta_{\mathrm{H}}\left(\mathrm{CDCl}_{3}, 300 \mathrm{Mhz}\right) 8.9(1 \mathrm{H}$, br s, $-\mathrm{NH}), 6.65-7.2(4 \mathrm{H}, \mathrm{m}, \mathrm{Ar}-\mathrm{H})$, $3.75\left(3 \mathrm{H}, \mathrm{s},-\mathrm{CO}_{2} \mathrm{CH}_{3}\right), 3.2-0.7(15 \mathrm{H}, \mathrm{m})$, and $0.6 \mathrm{ppm}\left(3 \mathrm{H}, \mathrm{t}, \mathrm{J}=7 \mathrm{~Hz},-\mathrm{CH}_{3}\right)$; 13C-NMR: $\delta_{\mathrm{C}}$ 169.05 (- $\left.\mathrm{CO}_{2} \mathrm{Me}\right), 167.61$ (C-2), 143.17 (C-13), 137.77 (C-8), 127.36 (C-11), 120.29 (C-9), 120.43 (C10), 109.23 (C-12), 92.52 (C-16), 72.5 (C-21), 55.42 (C-7), 51.69 (C-3), 50.9 (-OCHH 3 ), 50.56 (C-5), 45.1 (C-6 ), 38.08 (C-20), 32.8 (C-5), 25.57 (C-17), 29.31 (C-19) and 7.09 ppm (C-18); MS m/z (\%) $338\left(\mathrm{M}^{+}, 5.6\right), 144(0.4), 143(0.5), 130(0.6), 125$ (9.4), $124(100)$ and $96(1.9)$. 


\section{6-Hydroxy-1,2-dehydrovincadifformine (3)}

$( \pm)$ Vincadifformine $(0.5 \mathrm{~g}, 1.47 \mathrm{mmol})$ in a solution of Rose Bengal $\left(1.5 \times 10^{-4} \mathrm{M}\right)$ in methanol water $(6: 1,37.5 \mathrm{~mL})$ containing sodium thiosulphate $(0.35 \mathrm{~g}, 2.2 \mathrm{mmol})$ and $2 \mathrm{~N}$ sodium hydroxide solution $(0.5 \mathrm{~mL})$ was irradiated for $1 \mathrm{~h}$ between $20-30{ }^{\circ} \mathrm{C}$ using two $150 \mathrm{~W}$ tungsten lamps in the presence of oxygen. Sodium tetrathionate was filtered off and the solvent removed under reduced pressure $\left(\mathrm{t}_{\text {bath }}<40^{\circ} \mathrm{C}\right)$, then the crude product was filtered through a short column of neutral alumina to remove the sensitiser using chloroform - methanol (19:1) as eluent. After removal of the solvent, the crude products were chromatographed on silica gel (15 g), eluting with chloroform - ethyl acetate (2:1) to give two main fractions: (a) starting material, verified by TLC comparison with an authentic sample, IR and NMR; (b) the second fraction contained 16-hydroxy-1,2-dehydrovinca-difformine (3) (151 mg, $30 \%$ ) as an orange solid, m.p. $109-110^{\circ} \mathrm{C}$ (lit.[9] m.p. $\left.112^{\circ} \mathrm{C}\right)$; IR: $v_{\max }\left(\mathrm{CHCl}_{3}\right) 3450$ (br), 1738 (unconjugated ester cabonyl) and $1450 \mathrm{~cm}^{-1}$; UV: $\lambda_{\max }(\mathrm{MeOH}) 210,224(\mathrm{sh}), 264 \mathrm{~nm}$ and $\lambda_{\min } 240$ $\mathrm{nm} ;{ }^{1} \mathrm{H}-\mathrm{NMR}: \delta_{\mathrm{H}}\left(\mathrm{CDCl}_{3}, 90 \mathrm{MHz}\right) \mathrm{NH}$ was absent, $7.6(1 \mathrm{H}, \mathrm{s}, 9-\mathrm{H}), 7.1-7.4(3 \mathrm{H}, \mathrm{m}, \mathrm{Ar}-\mathrm{H}), 3.96(3$ $\left.\mathrm{H}, \mathrm{s},-\mathrm{CO}_{2} \mathrm{Me}\right) 3.8-1.2(15 \mathrm{H}$, complex $)$ and $0.5\left(3 \mathrm{H}, \mathrm{t}, \mathrm{J}=6.6 \mathrm{~Hz},-\mathrm{CH}_{3}\right) ; \mathrm{MS}: \mathrm{m} / \mathrm{z}(\%) 354\left(\mathrm{M}^{+}, 72.2\right)$, $336(25.9)\left[\mathrm{M}^{+}-\mathrm{H}_{2} \mathrm{O}\right], 295$ (26.9) $\left[\mathrm{M}^{+}-\mathrm{CO}_{2} \mathrm{Me}\right], 266$ (Et, 95), 138 (9.6) and 124 (22.5).

\section{6-Hydroxy-1,2-dehydrovincadifformine- $N_{b}$-oxide}

A stirred solution of $( \pm)$-vincadifformine $(0.2 \mathrm{~g}, 0.58 \mathrm{mmol})$ in anhydrous benzene $(6 \mathrm{~mL})$ was treated in small portions with $\underline{\mathrm{m}}$-chloroperbenzoic acid (224 mg, $1.3 \mathrm{mmol}, 2.2$ equiv.) at ambient temperature, in the dark. Stirring was continued for $36 \mathrm{~h}$ under a nitrogen atmosphere. The solvent was removed under reduced pressure $\left(\mathrm{t}_{\text {bath }}<40^{\circ} \mathrm{C}\right)$ and the residue was taken up in dichloromethane. The mixture was washed with $10 \%$ sodium sulphite solution $(30 \mathrm{~mL}), 5 \%$ sodium bicarbonate solution, and water, then dried $\left(\mathrm{MgSO}_{4}\right)$ and concentred under reduced pressure $\left(\mathrm{t}_{\text {bath }}<40^{\circ} \mathrm{C}\right)$. Chromatography on silicagel G (30 g) using a 5:3.9:1:0.1 mixture of benzene - methanol - ether and ammonia as eluent afforded 16-hydroxy-1, 2-dehydrovincadifformine $\mathrm{N}_{\mathrm{b}}$-oxide (4) (170 mg, 77.9\%), which was recrystalised from dichloromethane-ether to give colourless prisms, m.p. $176-78{ }^{\circ} \mathrm{C}$ (dec.); Anal. Found: C, 67.9; H, 7.1; N, 7.55; Calc. for $\mathrm{C}_{21} \mathrm{H}_{26} \mathrm{~N}_{2} \mathrm{O}_{4}$ : C, 68.1; H, 7.0; N, 7.6 \%); IR: $v_{\max }\left(\mathrm{CHCl}_{3}\right)$ $3450(\mathrm{OH}), 3100-2900,2809,1738$ (unconjugated ester carbonyl), 1570, 1450, 1280-1230 and $663 \mathrm{~cm}$ ${ }^{-1}$; UV: $\lambda_{\max }(\mathrm{MeOH}) 223,270 \mathrm{~nm} ;{ }^{1} \mathrm{H}-\mathrm{NMR}: \delta_{\mathrm{H}}\left(\mathrm{CDCl}_{3}, 90 \mathrm{MHz}\right), 8.0(1 \mathrm{H}, \mathrm{m},-\mathrm{OH}) 7.6$ (1 H, dd, 9$\mathrm{H})$, 7.5-7.1 (3 H, m, Ar-H), $3.95\left(3 \mathrm{H}, \mathrm{s},-\mathrm{CO}_{2} \mathrm{Me}\right), 2.64(1 \mathrm{H}, \mathrm{s}, 21-\mathrm{H}), 3.4-1.2(14 \mathrm{H}$, complex $)$ and 0.5 ppm $(3 \mathrm{H}, \mathrm{t}, \mathrm{J}=7 \mathrm{~Hz}, 18-\mathrm{H})$; ${ }^{13} \mathrm{C}-\mathrm{NMR}: \delta_{\mathrm{C}} 180(\mathrm{C}-2), 171.87$ (C-22), 152 (C-13), $146(\mathrm{C}-8), 127.98(\mathrm{C}-$ 11), 127.79 (C-10), 124.6 (C-9), 120.05 (C-12 ), 83 (C-21), 76.6 (C-16), 67 (C-3), 65 (C-5), 58 (C-7), 53.11 (- $\left.\mathrm{CO}_{2} \mathrm{CH}_{3}\right), 40.62$ (C-17), 36.43 (C-20), 35.11 (C-19), 31.46 (C-15), 18.8 (C-14), 7.4 (C-18); MS: m/z (\%) $370\left(\mathrm{M}^{+}, 10.2\right), 253$ (15.4), 252 (3.3), 267 (5.1), 144 (9.1), 130 (18.2) and 124 (30.9).

The less polar fraction contained vincadifformine- $\mathrm{N}_{\mathrm{b}}$-oxide $\left(36 \mathrm{mg}, 18 \%\right.$ ), m.p. $160^{\circ} \mathrm{C}$ (dec.), IR: $v_{\max }\left(\mathrm{CHCl}_{3}\right) 1690$ and $1615 \mathrm{~cm}^{-1}$; UV: $\lambda_{\max }(\mathrm{MeOH}) 227,297$ and $330 \mathrm{~nm} ;{ }^{1} \mathrm{H}-\mathrm{NMR}: \delta_{\mathrm{H}}\left(\mathrm{CDCl}_{3}, 90\right.$ $\mathrm{MHz})$ 7.65-7.2 (4 H, m, Ar-H), $3.9\left(3 \mathrm{H}, \mathrm{s},-\mathrm{CO}_{2} \mathrm{Me}\right), 3.8(1 \mathrm{H}, \mathrm{s}, 21-\mathrm{H}), 3.45-1.2(15 \mathrm{H}, \mathrm{m})$ and 0.5 


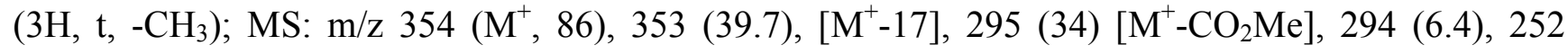
(100), 265 (4.5), 144 (6.3), 143 (12.9) and 124 (21.3).

\section{6-Oxoaspidospermidine- $N_{b}$-oxide (5a)}

m-Chloroperbenzoic acid $(1.128 \mathrm{~g}, 6.5 \mathrm{mmol})$ was added in small portions to a stirred solution of vincadifformine $(1 \mathrm{~g}, 2.9 \mathrm{mmol})$ in dry benzene $(150 \mathrm{~mL})$ under a nitrogen atmosphere. The reaction mixture was stirred continuously for $24 \mathrm{~h}$ at room tempurature in the dark, after which the solvent was removed under reduced pressure $\left(\mathrm{t}_{\text {bath }}<40^{\circ} \mathrm{C}\right)$. The residue was taken up in $1.25 \mathrm{M}$ sodium hydroxide solution $(100 \mathrm{~mL})$ and the resulting solution was stirred at ambient temperature under a nitrogen atmosphere in the dark for $2.5 \mathrm{~h}$. Then the solution was acidified with $1.25 \mathrm{M}$ hydrochloric acid solution to $\mathrm{pH} 1$, and stirred vigorously at $100^{\circ} \mathrm{C}$ for 20 minutes under a nitrogen atmosphere. After cooling the mixture was extracted with ether $(5 \mathrm{x} 60 \mathrm{~mL})$. The aqueous phase was then made alkaline with sodium hydroxide solution, saturated with $\mathrm{NaCl}$ and extracted with dichloromethane $(5 \times 60 \mathrm{~mL})$. The combined organic fraction were dried $\left(\mathrm{Na}_{2} \mathrm{SO}_{4}\right)$ and evaporated under reduced pressure to give 16oxoaspidospermine- $\mathrm{N}_{\mathrm{b}}$-oxide (5a) $(0.915 \mathrm{~g}, 98 \%)$ as a yellow amorphous solid; IR $v_{\max }\left(\mathrm{CHCl}_{3}\right) 3040$ $2880 \mathrm{~cm}^{-1}, 1700$ (-CO), 1610, 1470, 1275, 1110, 920, 715 and $670 \mathrm{~cm}^{-1}$; UV: $\lambda_{\max }(\mathrm{MeOH}) 218,243$ (sh) and $300 \mathrm{~nm} ;{ }^{1} \mathrm{H}-\mathrm{NMR}: \delta_{\mathrm{H}}\left(\mathrm{CDCl}_{3}, 90 \mathrm{MHz}\right) 8.25(1 \mathrm{H}, \mathrm{br}, \mathrm{NH}), 7.5-6.5(4 \mathrm{H}, \mathrm{m}, \mathrm{Ar}-\mathrm{H}), 5(1 \mathrm{H}, \mathrm{s}$, H-21) 4-1.1 (16 H, complex) and 0.7 ppm (3H, t, J=6.5 Hz, - $\left.\mathrm{CH}_{3}\right)$; MS: m/z (\%) $312\left(\mathrm{M}^{+}, 0.9\right), 296$ (6.9) $\left[\mathrm{M}^{+}-16\right], 295$ (19.2), 294 (100), 293 (59.6), 268 (4), 144 (16.8), 138 (32.3), 130 (34.4) and 124 (20.1).

\section{6-Oxoaspidospermidine (5b)}

A suspension of 16-oxoaspidospermidine- $\mathrm{N}_{\mathrm{b}}$-oxide (5a) $(0.9 \mathrm{~g}, 2.8 \mathrm{mmol})$ and platinium (IV) oxide $(122 \mathrm{mg}, 0.53 \mathrm{mmol})$ in methanol $(20 \mathrm{~mL})$ was hydrogenated at room temperature and atmospheric pressure for $3 \mathrm{~h}$. The catalyst was removed by filtration. Concentration under reduced pressure gave 16-oxoaspidospermidine $(0.75 \mathrm{~g}, 88 \%)$, which was recrystallised from methanol to afford colouress prisms; m.p. $108-112{ }^{\circ} \mathrm{C}$; Anal. Found: C, 68.3; H, 7.65; N, 7.5\%; Calc. for $\mathrm{C}_{19} \mathrm{H}_{24} \mathrm{~N}_{2} \mathrm{O}$ : C, 68.5; H, 7.5; N, 8\%); IR: $v_{\max }$ (nujol) 3345, $1720(\mathrm{CO}), 1610,1475,1385$ and $730 \mathrm{~cm}^{-}$ 1; UV: $\lambda_{\max }(\mathrm{MeOH}) 210,240$ and 292, $\lambda_{\min } 262 \mathrm{~nm} ;{ }^{1} \mathrm{H}-\mathrm{NMR}: \delta_{\mathrm{H}}(\mathrm{MeOD}, 300 \mathrm{MHz}) 7.22-6.81(4 \mathrm{H}$, $\mathrm{m}, \mathrm{Ar}-\mathrm{H}), 4.9(1 \mathrm{H}, \mathrm{s}, 21-\mathrm{H}), 4-0.98\left(16 \mathrm{H}\right.$, complex), and $0.79 \mathrm{ppm}\left(3 \mathrm{H}, \mathrm{t}, \mathrm{J}=7 \mathrm{~Hz},-\mathrm{CH}_{3}\right) ; \mathrm{MS}: \mathrm{m} / \mathrm{z}(\%)$ $296\left(\mathrm{M}^{+}, 8.8\right), 268(10)\left[\mathrm{M}^{+}-\mathrm{CO}\right], 144$ (18.6), 138 (100), 130 (6.4), and 124 (18.1).

\section{6-Hydroxyaspidospermidine (6)}

To a solution of 16-oxoaspidospermidine $(\mathbf{5 b})(1.71 \mathrm{~g}, 5.7 \mathrm{mmol})$ in ethanol $(400 \mathrm{~mL})$ sodium borohydride $(5.97 \mathrm{~g}, 0.15 \mathrm{~mol})$ was added in portions with stirring at ambient temperature. After the addition was complete, the resulting mixture was refluxed for $4 \mathrm{~h}$, then allowed to cool before being diluted with water. The mixture was concentrated under reduced pressure and the residue was taken up 
in water $(100 \mathrm{~mL})$, then extracted with dichloromethane $(3 \times 200 \mathrm{~mL})$. The combined organic phases were dried $\left(\mathrm{MgSO}_{4}\right)$ and then concentrated under reduced pressure. The residue was purified by chromatography on Kieselgel G (40 g) using chloroform - methanol (9:1) as eluent, which gave two main fractions: (a) the less polar fraction contained colouress plates of $16 \beta$-hydroxyaspidospermidine (6a) (1.24 g, 72.5\%), m.p. 55 C; Anal. Found: C, 76.75; H, 9.05; N, 9.0; Calc. for $\mathrm{C}_{19} \mathrm{H}_{26} \mathrm{~N}_{2} \mathrm{O}$ : C, 76.5; H, 8.70; N, 9.0\%; IR: $v_{\max }\left(\mathrm{CHCl}_{3}\right) 3420(-\mathrm{OH}), 3000-2705,1600,1480,1460,1312,1250,1030,900$, and $630 \mathrm{~cm}^{-1} ; \lambda_{\max }(\mathrm{MeOH}) 212,244,300 ;{ }^{1} \mathrm{H}-\mathrm{NMR}: \delta_{\mathrm{H}}\left(\mathrm{CDCl}_{3}, 400 \mathrm{MHz}\right) 7.05(2 \mathrm{H}, \mathrm{m}, \mathrm{Ar}-\mathrm{H}), 6.7$ $(1 \mathrm{H}, \mathrm{t}, \mathrm{J}=7 \mathrm{~Hz}), 6.55(1 \mathrm{H}, \mathrm{d}, \mathrm{J}=7 \mathrm{~Hz}, \mathrm{Ar}-\mathrm{H}), 4.85(1 \mathrm{H}, \mathrm{m}, 16-\mathrm{H}), 3.77(1 \mathrm{H}, \mathrm{d}, \mathrm{J}=4 \mathrm{~Hz}, 2-\mathrm{H}), 3-0.8$ $(17 \mathrm{H}, \mathrm{m})$, and $0.55 \mathrm{ppm}\left(3 \mathrm{H}, \mathrm{t}, \mathrm{J}=7.5 \mathrm{~Hz},-\mathrm{CH}_{3}\right) ;{ }^{13} \mathrm{C}-\mathrm{NMR}: \delta_{\mathrm{C}} 150.37(\mathrm{C}-13), 136.01(\mathrm{C}-8), 127$ (C-11), 123 (C-9), 118.4 (C- 10), 109.26 (C-12), 74.49 (C-21), 71.01 (C-2), 67.65 (C-16), 54.1 (C-7), 53.15 (C-3), 52.49 (C-5), 43.0 (C-6), 36.11 (C -20), 35.97 (C-17), 34.7 (C-15), 34.23 (C-19), 22.10 (C-14) and 7.75 ppm $\left(\mathrm{CH}_{3}\right)$; MS: m/z (\%) $298\left(\mathrm{M}^{+}, 5.7\right), 254$ (8.7), 144 (5.3), 138 (1.5), 130 (5.5) and 124 (100); (b) The more polar fraction corresponds to the second epimer, 16 $\alpha$-hydroxyaspidospermidine (6b) (212 mg, $12.3 \%$ ), which was obtained as an amorphous solid; IR: $v$ max $\left(\mathrm{CHCl}_{3}\right)$ $3400 \mathrm{~cm}^{-1}(\mathrm{OH}), 3000,2940,2860,2700,1605,1480,1460$, and $670 \mathrm{~cm}^{-1}$; UV: $\lambda_{\max } 212,242$ and 296 $\mathrm{nm} ;{ }^{1} \mathrm{H}-\mathrm{NMR}: \delta_{\mathrm{H}}\left(\mathrm{CDCl}_{3}, 300 \mathrm{MHz}\right)$ 7.25-6.6 (4H, m, Ar-H ), $3.6(1 \mathrm{H}, \mathrm{m}, 16-\mathrm{H}), 4(1 \mathrm{H}, \mathrm{s},-\mathrm{OH}), 3.5$ $(1 \mathrm{H}, \mathrm{m}, \mathrm{H}-2), 3.8-0.8(16 \mathrm{H}, \mathrm{m}), 0.6\left(3 \mathrm{H}, \mathrm{t}, \mathrm{J}=7 \mathrm{~Hz},-\mathrm{CH}_{3}\right) ; \mathrm{MS}: \mathrm{m} / \mathrm{z}(\%) 298\left(\mathrm{M}^{+}, 5.8\right), 249$ (6.2), 168 (18.3), 144 (13.5), 138 (3.1), 130 (16.1) and 124 (100).

\section{$N_{a}$-Formyl-16 $\beta$-formyloxyaspidospermidine (7a).}

To a stirred solution of $16 \beta$-hydroxyaspidospermidine (6a) $(121 \mathrm{mg}, 0.4 \mathrm{mmol})$ in formic acid $(5.47 \mathrm{~mL}, 6.6 \mathrm{mg}, 0.14 \mathrm{~mol})$ at $0^{\circ} \mathrm{C}$, acetic anhydride $(0.54 \mathrm{~mL}, 59 \mathrm{mmol})$ was added dropwise over 10 minutes. The resulting reaction mixture was stirred at room temperature for $18 \mathrm{~h}$ and then concentrated under reduced pressure. The residue was purified by chromatography on kieselgel G (20 g) with dichloromethane/methanol (2\%) as the eluent, to give the $\mathrm{N}_{\mathrm{a}}$-formyl-16 $\beta$-formyloxyaspidospermidine 7a (130 mg, $90.1 \%$ ) as colourless plates, m.p. 70-2 ${ }^{\circ} \mathrm{C}$; Anal. Found: C, 71.4; H, 7.6; N, 8; HRMS $\mathrm{M}^{+}, \mathrm{m} / \mathrm{z}$ 354.19138; $\mathrm{C}_{21} \mathrm{H}_{26} \mathrm{~N}_{2} \mathrm{O}_{3}$ requires C, 71.18; H, 7.34; $\mathrm{M}^{+}, \mathrm{m} / \mathrm{z}$ 354.1913; IR: $v_{\max }\left(\mathrm{CHCl}_{3}\right) 3019$, 2943, 2900, 2800, 2740, 1720, 1670, 1600, 1480, 1460, 1400, 1361 and $1180 \mathrm{~cm}^{-1}$; UV: $\lambda_{\max }(\mathrm{MeOH})$ 210, 250, 282, 290, $\lambda_{\min } 226,270 \mathrm{~nm} ;{ }^{1} \mathrm{H}-\mathrm{NMR}: \delta_{\mathrm{H}}\left(\mathrm{CDCl}_{3}, 300 \mathrm{MHz}\right), 8.9(1 \mathrm{H}, \mathrm{s},-\mathrm{CHO}), 8.6(1 \mathrm{H}, \mathrm{s}$, -CHO), 7.9 (dd, J=9.3 and $18 \mathrm{~Hz}, 12-\mathrm{H}), 7.15-7(3 \mathrm{H}, \mathrm{m}, \mathrm{Ar}-\mathrm{H}), 5.75(1 \mathrm{H}, \mathrm{m}, 16-\mathrm{H}), 4.6(1 \mathrm{H}, \mathrm{d}, \mathrm{J}=5 \mathrm{~Hz}$, 2-H), $3(2 \mathrm{H}, \mathrm{m}), 2.4-0.8(13 \mathrm{H}, \mathrm{m})$, and $0.7\left(3 \mathrm{H}, \mathrm{t}, \mathrm{J}=6 \mathrm{~Hz},-\mathrm{CH}_{3}\right) ;{ }^{13} \mathrm{C}-\mathrm{NMR}: \delta_{\mathrm{C}} 160.187,160.35$ (-NCHO), 160.05, 157.89, (-OCHO), 140.97 (C-13), 138.46 (C-8), 127.81, 127.62 (C-16), 124.79, 124.64 (C-11), 123.17, 122.28 (C -9), 116.153 (C- 10) 109.05 (C-12), 71.05, 70.29 (C-21), 70.14, 68.8 (C-2), 66.4,63.7 (C - 7), 53.32, 52.96 (C- 3), 51.89, 51.76 (C - 5), 41.11, 40.67 (C-6), 35.04, 34.94 (C-20), 34.84, 34.64 (C-17), 32.76, 32.15 (C-15), 27.9, 26.61 (C-19), 21.57, 21.46 (C-14) and 7.12, $6.95\left(-\mathrm{CH}_{3}\right)$; MS: m/z (\%) $354\left(\mathrm{M}^{+}, 1.9\right), 326$ (0.9), 325 (0.9), 282 (3.9), 144 (4.5), 130 (5.2), 124 (100) and 29 (CHO, 15.9). 
$N_{a}$-Formyl -16 $\beta$ - hydroxyaspidospermidine (1a)

To a stirred solution of $\mathrm{N}_{\mathrm{a}}$-formyl-16 $\beta$-formyloxyaspidosperminidine (7a) (76 $\mathrm{mg}, 0.2 \mathrm{mmol}$ ) in methanol $(1 \mathrm{~mL})$ sodium carbonate solution $(1 \mathrm{~mL})$ was added. The resulting reaction mixture was stirred at room temperature for 15 minutes. Concentration under reduced pressure gave a residue which was taken up in ethyl acetate, washed with water $(15 \mathrm{~mL})$, and dried over magnesium sulphate. Removal of the solvent under reduced pressure gave a yellow solid, which was purified by chromatography on Kieselgel G (25 g) using dichloromethane/ether (1:1) as eluent, which gave $\mathrm{N}_{\mathrm{a}^{-}}$ formyl-16 $\beta$-hydroxyaspidospermidine (1a) $(68.5 \mathrm{mg}, 98 \%)$ as colouress plates, m.p. $66-68{ }^{\circ} \mathrm{C}$; Anal. Found: C, 73.40; H, 8.15; N, 8.25\%; $\mathrm{C}_{20} \mathrm{H}_{26} \mathrm{~N}_{2} \mathrm{O}_{2}$ requires C, 73.6; H, 8.0; N, 8.5\%); IR $v_{\max }\left(\mathrm{CHCl}_{3}\right)$ 3360 (br, OH), 3010, 2945, 2860, 2798, 2738, 1680, 1600, 1490, 1460, 1365, 1335, 1180, 1080, 908 and $675 \mathrm{~cm}^{-1}$; UV: $\lambda_{\max }(\mathrm{MeOH}) 210,253,260(\mathrm{sh}), 280,290 \mathrm{~nm}$ and $\lambda_{\min } 266,270 \mathrm{~nm}$; 1H-NMR: $\delta_{\mathrm{H}}\left(\mathrm{CDCl}_{3}, 300 \mathrm{Mhz}\right)$ 9-8.72 (1 H, 2s, -NCㅌO), $8.03(1 \mathrm{H}, \mathrm{d}, \mathrm{J}=9 \mathrm{~Hz}, 12-\mathrm{H}), 7.2-7(3 \mathrm{H}, \mathrm{m}, \mathrm{Ar}-\mathrm{H}), 5$ $(1 \mathrm{H}$, br s, 16-H), $4.15(1 \mathrm{H}, \mathrm{d}, \mathrm{J}=4.6 \mathrm{~Hz}, 2-\mathrm{H}), 3.2-0.6(16 \mathrm{H}, \mathrm{m})$ and $0.55 \mathrm{ppm}(3 \mathrm{H}, \mathrm{t}, \mathrm{J}=7.4 \mathrm{~Hz}$, - $\left.\mathrm{CH}_{3}\right) ;{ }^{13} \mathrm{C}-\mathrm{NMR}: \delta_{\mathrm{C}} 159.82(\mathrm{NC} H \mathrm{HO}), 142.233(\mathrm{C}-13), 138(\mathrm{C}-8), 128.02(\mathrm{C}-6), 125.11(\mathrm{C}-11), 124.15$ (C-9), 116 (C-10), 109.6 (C-12), 74.1 (C-21), 71.84 (C-2), 65.23 (C-7), 52.9 (C-3), 52.47 (C-5), 41.26 (C-6), 35.79 (C-20), 35.46 (C-17), 34.35 (C-19), 33.62 (C-15), 21.86 (C-14), 7.58 (C-18); MS: m/z (\%) $326\left(\mathrm{M}^{+}, 5.7\right), 325$ (0.9), 309 (0.2), 298 (0.6), 297 (0.4), 282 (5.4), 149 (6.1), 144 (2.8), 143 (1.5), 138 (2.5), 130 (1.9), 124 (100), 122 (1), 110 (1.7), 109 (2.6), 96 (2.3).

$N_{a}$-Formyl-16 $\alpha$-hydroxyaspidospermidine (1b)

To a solution of $16 \alpha$-hydroxyaspidospermidine $(90 \mathrm{mg}, 0.3 \mathrm{mmol})$ in formic acid $(4 \mathrm{~mL}, 4.87 \mathrm{~g}$, $0.1 \mathrm{~mol})$ at $0{ }^{\circ} \mathrm{C}$, acetic anhydride $(0.4 \mathrm{~mL}, 17.6 \mathrm{mmol})$ was added dropwise. The mixture was stirred at room temperature for $18 \mathrm{~h}$, then concentrated under reduced pressure. The residue was taken up in methanol $(1 \mathrm{~mL})$, and sodium carbonate solution $(1 \mathrm{~mL})$ was added. The reaction mixture was then stirred for 20 minutes. Removal of the solvent under reduced pressure gave a yellow oily residue which was purified by chromatography on silica gel G (15 g) with dichloromethane/5\% methanol as the eluent, to afford the $\mathrm{N}_{\mathrm{a}}$-formyl-16 $\alpha$-hydroxy-aspidospermidine (1b) (76 $\mathrm{mg}, 77 \%$ ) as a clear, yellow oil; HRMS: Found: $\mathrm{M}^{+}, \mathrm{m} / \mathrm{z}$ 326.200, $\mathrm{C}_{20} \mathrm{H}_{26} \mathrm{~N}_{2} \mathrm{O}_{2}$ requires $\mathrm{M}^{+}, \mathrm{m} / \mathrm{z}$ 326.1994); IR: $v_{\max }$ $\left(\mathrm{CHCl}_{3}\right) 3450$ (br, OH), 3010, 2940, 2860, 1660, 1405, $1125 \mathrm{~cm}^{-1}$; UV: $\lambda_{\max }(\mathrm{MeOH}) 212,253,260$ (sh), 280, $290 \mathrm{~nm} ;{ }^{1} \mathrm{H}-\mathrm{NMR}: \delta_{\mathrm{H}}\left(\mathrm{CDCl}_{3}, 400 \mathrm{MHz}\right)$ 9-8.86 (1H, 2s, NCHO), $8.08(1 \mathrm{H}, \mathrm{d}, \mathrm{J}=9.1 \mathrm{~Hz}$, 12-H), 7.3-7 (3H, m, Ar-H), $4.37(1 \mathrm{H}, \mathrm{d}, \mathrm{J}=7.5 \mathrm{~Hz}, 2-\mathrm{H})$ and $0.7 \mathrm{ppm}\left(3 \mathrm{H}, \mathrm{t}, \mathrm{J}=7 \mathrm{~Hz}, \mathrm{CH}_{3}\right)$; ${ }^{13} \mathrm{C}-\mathrm{NMR}$ : $\delta_{\mathrm{C}} 160.2(\mathrm{NC}-\mathrm{HO}), 142$ (C-13), 138.62 (C-8), 127.86 (C-16), 125.43 (C-11), 123.52 (C-9), 110.54 (C-2), 73.85 (C-21), 71.39 (C-2), 64 (C-7), 53.40 (C-3), 52.64 (C-5), 42.23 (C-6), 36.74 (C-20), 34.31 (C-19), 32.78 (C-15), 31.30 (C-17), 21.38 (C-14) and 6.8 (C-18); MS: m/z (\%) $326\left(\mathrm{M}^{+}, 123\right), 325$ (4.3), 309 (6.3), 298 (4.4), 297 (1.8), 282 (8.1), 152 (6.7), 149 (9.4), 144 (36.2), 143 (42.8), 138 (15.8), 130 (51.7), 124 (92.5), 122 (5.1), 110 (188), 109 (6.6), 96 (16.4). 


\section{References}

1. Atta-Ur-Rahman; Malik, S.; Phytochemistry, 1987, 26, 589

2. Khan, A. A.; Ashfaq, M.; Ali, M. N.; in Pharmacognostic Studies of Selected Indigenous Plant of Pakistan, Pakistan Forest Institute, Peshawar, 1979, p.75

3. Chopra, R. N.; Nayar, S. L.; Chopra, I.C.; in Glossary of Indian Medicinal Plants, C. S. I. R.: New Delhi, 1956, p. 212.

4. Kuehne, M. E.; Hafter, R.; Roland, D. M. J. Org. Chem., 1978, 43, 3705.

5. Kuehne, M. E.; Matsko, T. H.; Bohner, J. C.; Kirkemo, C. L. J. Org. Chem., 1979, 44, 1063.

6. Belferdi, F.; Bayoud, S.; Belattar, A., Magister Thesis, Constantine 1999.

7. Hugel, G.; Lévy, J.; Le Men, J. C.R. Seances Acad. Sci. Ser. C, 1972, 274, 1350.

8. Hugel, G.; Gourdier, B.; J. Lévy, J.; Le Men, J. Tetrahedron, 1980, 36, 511.

9. Calabi, L.; Danieli, B.; Lesma, G.; Palmisano, G. J. Chem. Soc. Perkin Trans. 1, 1982, 1371.

10. Hugel, G.; Gourdier, B.; Lévy, J.; Le Men, J. Tetrahedron Lett., 1974, 1597.

11. Orazi, O. O.; Cornal, R. A.; Holker, J. S. E.; Djerassi, C. J. Org. Chem., 1956, 21, 979.

Sample Availability: Samples are available from the authors.

(C) 2001 by MDPI (http://www.mdpi.org). Reproduction is permitted for noncommercial purposes. 